\title{
Brain Nucleus
}

National Cancer Institute

\section{Source}

National Cancer Institute. Brain Nucleus. NCI Thesaurus. Code C49346.

A mass of neuronal cells in a distinct area of the brain. 